$$
\begin{array}{r}
\text { Pontifícia Universidade Católica } \\
\text { do Rio de Janeiro }
\end{array}
$$

Rodrigo Mesquita Marinho

\title{
A Implantação da TV digital e a Mudança Organizacional
}

\section{Dissertação de Mestrado}

\begin{abstract}
Dissertação apresentada como requisito parcial para obtenção do grau de Mestre pelo Programa de Pósgraduação em Administração de Empresas do Departamento de Administração da PUC-Rio.
\end{abstract}

Orientadora: Profa. Sandra Regina da Rocha Pinto

Rio de Janeiro Janeiro de 2009 


$$
\text { Pontifícia Universidade C Católica }
$$

Rodrigo Mesquita Marinho

\title{
A Implantação da TV digital e a Mudança Organizacional
}

Dissertação apresentada como requisito parcial para obtenção do grau de Mestre pelo Programa de Pósgraduação em Administração de Empresas da PUC-Rio. Aprovada pela Comissão Examinadora abaixo assinada.

\author{
Prof ${ }^{a}$. Sandra Regina da Rocha Pinto \\ Orientadora \\ Departamento de Administração - PUC-Rio
}

Prof. José Roberto Gomes da Silva Departamento de Administração - PUC-Rio

Profa. Mônica Zaidan Gomes Rossi

FACC - UFRJ

Prof. Nizar Messari

Vice-Decano de Pós-Graduação do CCS

Rio de Janeiro, 05 de janeiro de 2009 
Todos os direitos reservados. É proibida a reprodução total ou parcial do trabalho sem autorização da universidade, do autor e da orientadora.

\section{Rodrigo Mesquita Marinho}

Graduou-se em Economia na Universidade Cândido Mendes no Rio de Janeiro. É agora analista em uma empresa de mídia e membro do conselho de administração de uma empresa de telecomunicações.

Ficha Catalográfica

Marinho, Rodrigo Mesquita

A implantação da TV digital e a mudança organizacional / Rodrigo Mesquita Marinho ; orientadora: Sandra Regina da Rocha Pinto. - 2009.

114 f. ; $30 \mathrm{~cm}$

Dissertação (Mestrado em Administração) - Pontifícia Universidade Católica do Rio de Janeiro, Rio de Janeiro, 2009.

Inclui bibliografia

1. Administração - Teses. 2. Mudança organizacional. 3. Inovação. 4. Modelo de gestão. 5. Perspectiva institucional. I. Pinto, Sandra Regina da Rocha. II. Pontifícia Universidade Católica do Rio de Janeiro. Departamento de Administração. III. Título.

CDD: 658 


\section{Resumo}

Marinho, Rodrigo Mesquita; Pinto, Sandra Reginada Rocha (Orientadora). A Implantação da TV digital e a Mudança Organizacional. Rio de Janeiro, 2009. 114p. Dissertação de Mestrado - Departamento de Administração, Pontifícia Universidade Católica do Rio de Janeiro.

As empresas estão cada vez mais expostas às influências do ambiente externo. Fatores como a globalização econômica, a intensificação da concorrência e a abertura dos mercados têm levado os gestores e estudiosos a procurar entender como as empresas podem atender às demandas, e influenciar o ambiente no qual elas estão inseridas. A as emissoras de televisão aberta estão passando por mudanças estimuladas por pressões institucionais e por avanços tecnológicos que o setor tem experimentado. O objetivo deste estudo foi identificar quais foram os impactos causados pela implantação da televisão digital na emissora de televisão aberta estudada. O que motivou a adoção da nova tecnologia, apenas possibilidades de melhora de resultado ou houve pressões externas que não deixaram alternativas senão a adoção da nova tecnologia? Foram realizadas entrevistas com oito diretores da empresa estudada. Os diretores entrevistados ocupam cargos nas áreas estratégicas da empresa. O resultado da pesquisa evidenciou que a implantação da tecnologia digital nas emissoras de televisão aberta não trará mudanças significativas no curto prazo, trata-se de uma mudança tecnológica. Apesar da nova tecnologia ter um alto potencial para estimular inovações, a empresa estudada está conservadora em relação aos investimentos necessários para a sua total difusão em função dos altos custos que tais investimentos implicariam para a empresa estudada e para os consumidores, sem que houvesse uma rentabilidade adequada. As emissoras de TV aberta adotaram a tecnologia digital em resposta ao crescimento de novas mídias como internet, celular e televisão por assinatura.

\section{Palavras-chave}

Mudança organizacional, inovação, modelo de gestão, perspectiva institucional. 


\section{Abstract}

Marinho, Rodrigo Mesquita; Pinto, Sandra Reginada Rocha (Advisor). The Introduction of digital TV and the Organizational Change. Rio de Janeiro, 2009. 114p. MSc Dissertation - Departamento de Administração, Pontifícia Universidade Católica do Rio de Janeiro.

Businesses are becoming more and more exposed to influences from the outside environment. Factors like economic globalization, the intensification of competition, and the opening of markets have led administrators and scholars to try to understand how businesses can satisfy demands and how to influence the environment in which they find themselves. Broadcasters of free-to-air (FTA) television are going through changes caused by institutional pressures and by technological advances that the sector has been testing. The objective of this research was to identify what the impacts occasioned by the introduction of digital television to the FTA broadcaster studied have been.

What has motivated the adoption of the new technology-only possibilities of improvements of the product, or were there external pressures that did not leave any alternative but to adopt the new technology? There were interviews with eight directors of the business studied. The directors interviewed are in charge of strategic areas in the business. The result of the research evinced that the introduction of digital technology into the broadcasters of FTA television will not bring about significant changes in the short term; it is a matter of a technological change. Despite the new technology having a high potential to spur innovations, the business studied is conservative in regard to the investments necessary for its complete distribution in function of the high costs that such investments would involve for the business studied and for the consumers, without there being an adequate profitability. The broadcasters of FTA television have adopted digital technology in response to the growth of new media like the Internet, cellphones, and pay TV.

\section{Keywords}

Organizational change, innovation, management role, institutional perspective. 


\section{Sumário}

1. INTRODUÇÃO 9

1.1. Contextualização do Problema 9

1.2. Objetivos 11

1.3. Delimitações do Estudo 12

1.4. Relevância do Estudo 13

1.5. Estrutura do Trabalho 14

2. REFERENCIAL TEÓRICO 15

2.1. Modelos de Gestão 15

2.2. Gerenciamento da Mudança 23

2.2.1. Inovação 23

2.2.2. Mudança Organizacional 30

2.3. Institucionalismo $\quad 46$

3. METODOLOGIA $\quad 64$

3.1. Tipo de pesquisa $\quad 64$

3.2. Coleta de dados 66

$\begin{array}{ll}\text { 3.3. Análise dos dados } & 70\end{array}$

3.4. Limitações do método $\quad 70$

4. RESULTADOS E DISCUSSÃO 72

4.1. Implicações das mudanças

4.1.1. Fatores que inviabilizam mudanças significativas e as mudanças que estão em curso $\quad 73$

4.1.1.1. Imagem com tecnologia HD e som Dolby 5.1 (seis canais) 74

4.1.1.2. Transmissão para celulares, televisões portáteis e televisões $\begin{array}{ll}\text { móveis } & 78\end{array}$

4.1.1.3. Interatividade $\quad 81$

4.1.1.4. Novos Players

4.2. As motivações para a adoção da tecnologia digital 86

4.3. A maneira de atuar 88

4.4. A amplitude das mudanças ocorridas ao longo da história da organização 95

5. CONSIDERAÇÕES FINAIS 105

5.1. Conclusão 105

5.2. Sugestões para Trabalhos Futuros 107

6. REFERÊNCIAS BIBLIOGRÁFICAS 109 


\section{Lista de Figuras}

Figura 1: Processo de formação da estratégia $\quad 22$

Figura 2: Ciclos de mudança organizacional $\quad 31$

Figura 3: Níveis de mudança organizacional 33

Figura 4: Compreendendo a mudança organizacional 35

Figura 5: Seqüências dos significados de mudanças 38

Figura 6: Estágios da mudança organizacional 43

Figura 7: Padrões de mudança organizacional 45

Figura 8: Níveis de mudança organizacional 96

Figura 9: Seqüências dos significados de mudanças 99

Figura 10: Processos reduzidos de mudança organizacional 100

Figura 11: Processos reduzidos de mudança organizacional 100

Figura 12: Processos reduzidos de mudança organizacional 101

$\begin{array}{ll}\text { Figura 13: Estágios da mudança organizacional } & 101\end{array}$

Figura 14: Padrões de mudança organizacional 103 


\section{Lista de Quadros}

Quadro 1: Relação entre determinantes organizacionais e inovação 24

Quadro 2: Conteúdos da mudança 32

Quadro 3: Comparação da Perspectiva Institucional e da Dependência de Recursos $\quad 58$

Quadro 4: Antecedentes Institucionais e Previsões de Respostas Estratégicas $\quad 60$

Quadro 5: Estratégias de Pesquisa 65 